\title{
BIOCHEMICAL AND MOLECULAR CHARACTERIZATION OF ANTAGONISTIC BACTERIA AGAINST YELLOW BLOTCH OF OYSTER MUSHROOM
}

\author{
Anand Kumar ${ }^{1}$, Shiv Kumar Verma ${ }^{2}$, Ashis ${ }^{3}$, Dhiraj Kumar Choudhary ${ }^{4}$ \\ ${ }^{I}$ Ph.D. Scholar, School of Biochemical engineering, IIT, BHU. India. \\ ${ }^{2}$ Ph.D. Scholar, School of Biochemical engineering, IIT, BHU. India. \\ ${ }^{3}$ Ph.D. Scholar, School of Biochemical engineering, IIT, BHU. India. \\ ${ }^{4}$ Ph.D. Scholar, School of Biochemical engineering, IIT, BHU. India.
}

\begin{abstract}
Yellow blotch of oyster mushroom (Pleurotus ostreatus) caused by Pseudomonas agarici is considered as a fatal disease to mushroom and diminish food quality for humans. Chemical control of yellow blotch in oyster mushroom has received little efficiency and these chemicals are hazardous to human life, decrease soil fertility and cause pollution. Alternatively biological control is the available strategy against soil borne diseases. The objectives of this research were 1.) To isolate different strains fluorescence, actinomycetes, and phosphate solublizing bacteria in rhizospheric soil from selected plants of different regions. 2.) To examine the antagonistic agent against Pseudomonas agarici. 3.) To characterize the antagonistic bacteria on the basis of biochemical and molecular (16S-r DNA sequencing). 50 strains of fluorescence, actinomycetes, and phosphate solublizing bacteria were collected from different regions. During examination of fluorescence strain $K 1, K 8, K 14$ were found antagonistic. The above consequences reveal that fluorescence bacteria have high capability of antagonistic property. During biochemical characterization on the basis of methyl-red, VogesProskauer, Indole Production IAA production, gram's staining, antibiotic assay it was found that antagonistic bacteria showed approximately the same result as Indole production, IAA production gram's negative and the MIC of Antibiotic assay. Strains were identified Pseudomonas fluorescence, according to the characteristics of its morphology and homology analysis (BLAST) of its 16S-r DNA sequencing.
\end{abstract}

Keywords: - Pseudomonas agarici, Yellow Blotch, Pleurotus ostreatus, 16 S rDNA Sequencing $* * *$

\section{INTRODUCTION}

In the oyster mushroom (Pleurotus ostreatus) a yellow blotch disease caused by pathogen Pseudomonas agarici was first observed in California in 1983, characterized by yellow droplets on their surface, stunted growth, yellow to orange colour change. [1] In the cultivated mushroom bacterial blotch disease caused by ion channel forming lipodepsipeptide toxin. [2] Microbial antagonist used to suppress disease as well as host specific pathogen to control weed population, the organism that suppress pest or pathogen is known as biological control agent.[3] Mechanism of Biological control of plant disease supported by metabolites produced by one organism may inhibit the other, lysis is not a primary mechanism in microbial antagonism in the soil. [4] Pseudomonas tolaasii causing bacterial blotch on cultivated oyster mushroom inhibited by sodium hypochlorite alkaline. [5] Antibiotic produced by antagonistic microorganism suppresses the various soil borne plant pathogen, In microbial interaction antibiotics have a significance in biocontrol. [6] Fluorescent pseudomonads a biocontrol agents is a alternative agent to manage soil borne plant pathogens, this produces polyketide 2,4-diacetylphloroglucinol (DAPG) so it have a important mechanism in biocontrol agent. [7] Biocontrol products increasing rapidly but about $1 \%$ of agricultural chemical sales [8] Under field conditions it is difficult to maintain consistent and effective control of plant disease; an effective biocontrol agent must be adapted to a certain environmental factors including host and soil.[9]

\section{MATERIAL AND METHODS}

Isolation of pathogenic Bacteria- The diseased mushroom took form lab and approach to isolate the pathogenic bacteria from diseased oyster mushroom described by Bessette (1985) used.

Collection of strains - Strains of bacteria from rhizospheric soil isolated by a serial dilution method from eastern and western region of Uttar Pradesh.

Antagonistic Screening of rhizospheric Bacteria against Pathogenic bacteria- Diffusion were applied for screening of antagonistic bacteria against pathogen. Poured the $25 \mathrm{ml}$ sterilized medium in sterilized petri plate. Incubate the plate for semi solidification for 30 minutes. Make a well in the 
center and 4 well around the center, drop the pathogenic broth culture in the central well and rhizospheric broth culture in another two well. Incubate for 24 hours.

\section{BIOCHEMICAL ANALYSIS OF}

\section{ANTAGONISTIC BACTERIA AGAINST PATHOGEN}

Analysis performed on the basis of following test-

1. Gram staining

2. Indole Production

3. Indole Acetic acid Production

4. Methyl-red \& Voges-Proskauer

5. Antibiotic assay

Gram's Staining - gram's staining performed on the simple procedure as mention in the protocol Indole ProductionPrepared $1 \%$ trypton broth, inoculate bacteria in trypton broth and kept one tube as an uninoculated comparative control. Incubate inoculated tubes at $35^{\circ} \mathrm{C}$ for 48 hours. After $48 \mathrm{hr}$. of incubation add $1 \mathrm{ml}$ of Kovac's reagent to each tube including control. Development of cherry (deep) red color in the top layer of tube in bacteria was found positive test. The absence of red coloration in bacteria was found indole negative. The quantity of indole measured by taking O.D in spectrophotometer

Methyl-red \& Voges - Proskauer test- Prepare MRVP broth tubes and inoculate the bacteria, keep one tube uninoculated for comparative control, incubate the tubes at $35^{\circ} \mathrm{C}$ for 48 hours. The methyl red indicator in the $\mathrm{pH}$ range will remain red and shows +ve test and yellow ve test. Development of a crimson -to ruby pink (red) color show +ve VP test and no color change -ve test

Antibiotic assay - Cultured bacteria in nutrient broth. 100$300 \mu 1$ of Nutrient broth culture poured in the sterilized petri plate. Add nutrient agar medium in petri plate and spread properly, make 3 well one in the center and another two at the periphery, poured the antibiotic stock solution of different conc. Incubate for $24 \mathrm{hrs}$. after incubation period observe MIC (Minimum Inhibition Concentration).

Indole acetic acid Production test- prepared $250 \mathrm{ml}$ of nutrient broth in 3 conical flasks, in the first flask add $1 \mathrm{mg} / \mathrm{ml}$ tryptophan, in second $3 \mathrm{mg} / \mathrm{ml}$ and in last $6 \mathrm{mg} / \mathrm{ml}$ of tryptophan. Transferred the nutrient broth media in a test tube, and inoculate bacteria in different conc. of tryptophan. Incubate for 10 days. Centrifuged $2 \mathrm{ml}$ bacterial culture at $10000 \mathrm{rpm}$ for 10 minutes. Took $2 \mathrm{ml}$ supernatant in vial add 2 drops of orthophosphoric acid in supernatant then add $4 \mathrm{ml}$ of Solawaski's regent. Sample gives strong red color IAA positive \& yellow IAA negative. Make $10 \mathrm{ml}$ standard stock solution of different conc. of IAA (40,60,80, 100, 150, 200,
250, 300) $\mu \mathrm{g} / \mathrm{ml}$. Took O.D. with the help of spectrophotometer at $530 \mathrm{~nm}$ absorbance.

\section{MOLECULAR CHARACTERIZATION OF ANTAGONISTIC BACTERIA-}

DNA isolation from bacteria - Bacterial genomic DNA isolated by minikit method (protocol by Geneaid).

\author{
PCR Amplification \\ Primer Sequences- \\ 5' AGAGTTGATCCTGGCTCAG3' 16S27 F \\ 5' AGGGTTGCGCTCGTTG3' 16 S 1115 R
}

PCR mix $(50 \mu l)$ was prepared by adding Taq DNA polymerase $1.25 \mathrm{U}$, dNTPs mixture $1 \mu \mathrm{l}$, Template DNA (60ng/ $\mu \mathrm{l}) 1 \mu \mathrm{l}$, Farward Primer $(10 \mathrm{pmol} / \mu \mathrm{l}) 1 \mu \mathrm{l}$, reverse primer (10 pmol/ $\mu \mathrm{l}) 1 \mu \mathrm{l}$, Buffer (10X) $5 \mu 1$.

Amplification was carried out as following reaction condition for 30 cycles.

Initial temperature $94^{\circ} \mathrm{C}$ for 120 seconds, denaturation $94^{\circ} \mathrm{C}$ for 30 second, annealing $48^{\circ} \mathrm{C}$ for 30 second, Extension $72^{\circ} \mathrm{C}$ for 60 second, Final extension $72^{\circ} \mathrm{C}$ for 120 seconds After amplification runs the PCR product in $1 \%$ agrose gel for detection.

$16 \mathrm{~S}$ r-DNA sequencing - sequenced the amplified DNA. After sequencing performed

NCBI BLAST, and compared homology with other strains of bacteria.

\section{RESULTS}

Pathogenic bacteria isolated from diseased mushroom, the growth rate was very fast as within $12 \mathrm{hrs}$ fill the whole petri plate, secrete some yellowish substances around the colony. Then Follow Kotch postulate and reinfect the pure mushroom and found diseased occurred on mushroom. During gram's staining it was found gram's positive.

Collection of Rhizospheric bacteria - 50 strains of bacteria collected from the soil samples of Varanasi, Mirzapur, Allahabad, Bareilly, Lucknow region. Strains of bacteria characterized by growing on the selective media as actinomycetes for actinomycetes bacterial, Pikovaskya for Phosphate solublizing bacteria, and king's B media for fluorescence bacteria After growing on selective media 12 strains were found actinomycetes, 25 strains fluorescence, and the rest were phosphate solublizing bacteria.

Antagonistic test- During antagonistic test 3 bacteria K1, K8, K14 were found antagonistic 


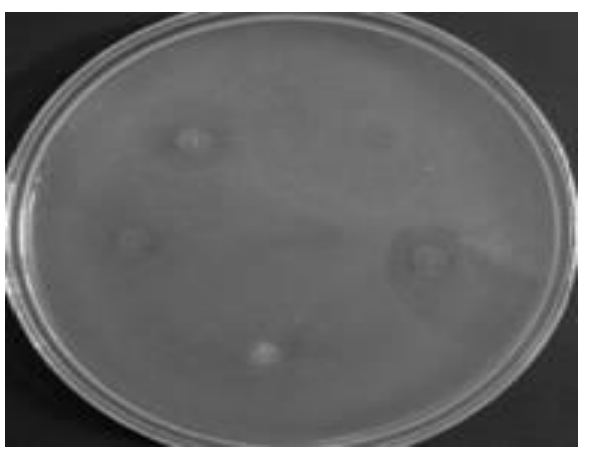

Antagonistic test

\section{BIOCHEMICAL TEST}

Gram's Staining- all the three strains were found gram's negative.

Indole Production- result was found that all the three strains of bacteria produce Indole.

Methyl red and Voges Proskauer Test- all the three strains of bacteria were found methyl-red Positive but Voges Proskauer negative.

Indole Acetic Acid Production - all the three strains produced approximate same amount of IAA on different conc. of tryptophan.

\begin{tabular}{|l|l|l|l|}
\hline \multirow{2}{*}{$\begin{array}{l}\text { Tryptophan } \\
\text { conc. }\end{array}$} & \multicolumn{3}{|l|}{ IAA production } \\
\cline { 2 - 4 } & $\mathrm{K} 1$ & $\mathrm{~K} 8$ & $\mathrm{~K} 14$ \\
\hline $1 \mathrm{mg} / \mathrm{ml}$ & $13.80 \mu \mathrm{g} / \mathrm{ml}$ & $14.00 \mu \mathrm{g} / \mathrm{ml}$ & $14.50 \mu \mathrm{g} / \mathrm{ml}$ \\
$2 \mathrm{mg} / \mathrm{ml}$ & $39.0 \mu \mathrm{g} / \mathrm{ml}$ & $40.0 \mu \mathrm{g} / \mathrm{ml}$ & $38.3 \mu \mathrm{g} / \mathrm{ml}$ \\
$3 \mathrm{mg} / \mathrm{ml}$ & $76.6 \mu \mathrm{g} / \mathrm{ml}$ & $75.0 \mu \mathrm{g} / \mathrm{ml}$ & $76.5 \mu \mathrm{g} / \mathrm{ml}$ \\
\hline
\end{tabular}

Antibiotic Assay - Minimum in hibition concentration of all three strains were found $150 \mathrm{mg} / \mathrm{ml}$.

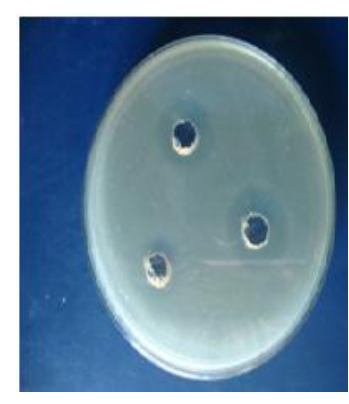

K1

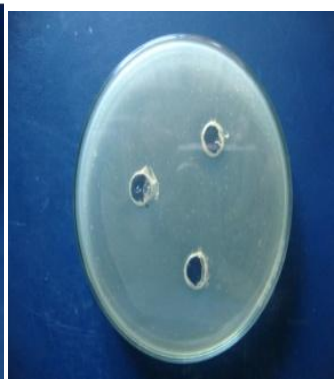

$\mathrm{K} 8$

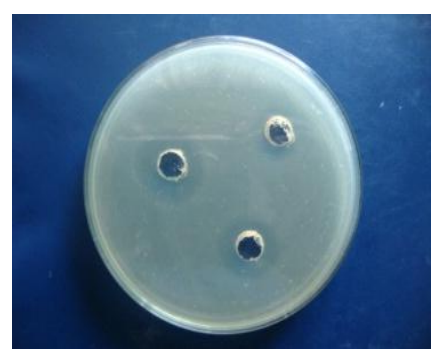

K14

Molecular Characterization- After $16 \mathrm{~S}$ r-DNA sequencing NCBI BLAST results were found as K1, K8, K14 strain have maximum identity with Pseudomonas fluorescence. On the basis of BLAST result it was found that K1, K8, K14 strains are Pseudomonas fluorescence.

\section{DISCUSSION}

Now Progressive research is fully concentrated on development of such type of tools which are pollution free and hazardous chemical less so the most of the scientist are aware for biocontrol agent for treating most of the disease in plants. These are important contributions because biocontrol agents offer disease management alternatives with different mechanisms of action than chemical pesticides. Trends in research include the increased use of biorational screening processes to identify microorganisms with potential for biocontrol, increased testing under semi commercial and commercial production conditions, increased emphasis on combining biocontrol strains with each other and with other control methods, integrating biocontrol into an overall system. Pseudomonas agarici a pathogenic bacteria was successfully isolated using the fruiting body of the oyster mushroom. The antagonistic K1, K8, K14 strain selected through the diffusion method showed a significant capability as biocontrol. To our knowledge, this screening model is novel. Compared with our previous work, the method is more effective in screening biocontrol agents against the disease caused by Pseudomonas agarici.

The Pseudomonas agarici growth was seriously inhibited by the $\mathrm{K} 1, \mathrm{~K} 8$, K14 strains, probably due to the antibacterial metabolites produced by $\mathrm{K} 1, \mathrm{~K} 8, \mathrm{~K} 14$. which leads to leaking out of the intracellular substances and blocks normal growth. sodium hypochlorite $(\mathrm{NaOCl})$ control bacterial blotch in Pleurotus ostreatus but high conc. of sodium hypochlorite also affect growth of oyster mushroom. [5] In case of biocontrole agent there is no antieffect of antagonistic organism. So this is better disease controlling method.

\section{REFRENCES}

[1]. Bessette A. E, Kerrigan R. W. and Jordan D. C. Yellow Blotch of Pleurotus ostreatus Appl. Environ. Microbiol. December vol. 50 no. 61535-1537 (1985) 
[2]. Brodey C L, Rainey P B, Tester M, Johnstone K. Bacterial blotch disease of the cultivated mushroom is caused by an ionchannel forming lipodepsipeptide toxin. Mol Plant-Microbe Interact.;4:407-411. (1991)

[3]. Pal, K. K. and B. McSpadden Gardener, 2006. Biological Control of Plant Pathogens. The Plant Health Instructor DOI: 10.1094/PHI-A--1117-02. (2006)

[4]. J.E. Mitchell The mechanisms of biological control of plant diseases, Soil Biology and Biochemistry, Volume 5, Issue 6, December, Pages 721-728 (1973)

[5]. Oh J. S., Kim K.H., Fermor R.T. Effect of sodium hypochloride for controlling Pleurotus ostreatus. The Korean society of mycology. Mycobiology 28 (3): 123-126 (2000)

[6]. Raaijmakers J. M., Vlami M. \& Souza J. T. de., Antibiotic production by bacterial biocontrol agents, antonie van leeuwenhoek Volume 81, Numbers 1-4, 537-547, DOI: 10.1023/A:1020501420831 (2002),

[7]. Notz,Regina E. Biotic factors affecting 2,4diacetylphloroglucinol biosynthesis in the model biocontrol strain Pseudomonas fluorescens CHA0, Swiss Federal Institute of Technology, Zürich Doctor of Natural Sciences (2002)

[8]. D.R. Fravel, Commercialization and implementation of biocontrol, Annu. Rev. Phytopathol. 43:337-59. (2005)

[9]. Sun J. B., Peng* M, Wang Y. G., Zhao P. J. and Xia Q. Y. Isolation and characterization of antagonistic bacteria against fusarium wilt and induction of defense related enzymes in banana African Journal of Microbiology Research Vol. 5(5) pp. 509-515, (2011 